\title{
Reporting plánů povodí podle Rámcové směrnice o vodách
}

\section{PETR VYSKOČ, HANA PRCHALOVÁ, SILVIE SEMERÁDOVÁ, TOMÁŠ FOJTíK}

\author{
Klíčová slova: Rámcová směrnice o vodách - plán povodí - reporting - stav vod - \\ vodní útvar - programy opatření - analýza vlivů a dopadů
}

\section{SOUHRN}

V roce 2015 bylo dokončeno zpracování plánů povodí pro 2. plánovací cyklus podle požadavků Rámcové směrnice o vodách (RSV). Následně byla zpracována a zkompletována a souhrnně vyhodnocena široká škála údajů pro potřeby splnění reportingových povinností vůči Evropské komisi. Přispěvek má informativní charakter. Je zaměřen na vlastní reporting (nikoli na samotné zpracování plánů povodí), shrnuje postup jeho přípravy a uvádí vybrané souhrnné údaje zaměěené na klíčové kroky k dosažení cílů RSV: určení antropogenních vlivů a dopadů na stav vod, hodnocení stavu vodních útvarů, stanovení výjimek z dosažení dobrého stavu a plánovaných opatření k dosažení environmentálních cílů.

\section{ÚVOD}

Národní plány povodí pro 2. plánovací cyklus [1-3], tj. na období let 2016 až 2021, zpracované podle požadavků Rámcové směrnice o vodách [4] (dále RSV) byly v prosinci 2015 schváleny vládou České republiky. V návaznosti na zpracování plánů povodí jsou členské státy EU povinny splnit příslušnou reportingovou povinnost týkající se podávání zpráv Evropské komisi (EK) o implementaci RSV. Kromě zaslání kopií plánů povodí EK od členských států vyžaduje rovněž poskytnutí dalších údajů souvisejících s celým procesem plánování. Požadavky na reporting 2. plánů podrobně specifikují př́slušné pokyny společné implementační strategie RSV $[5,6]$. Určitou komplikací bylo schválení konečné verze těchto dokumentů (včetně specifikace nároků na kvalitu dat) až v létě 2016, tj. několik měsíců po termínu reportingu podle RSV. Předmětem reportingu je rozsáhlá škála údajů týkajících se celého plánovacího procesu. Po formální stránce Ize reporting rozdělit na datovou část, která má charakter strukturované geodatabáze a obsahuje převážně podrobné údaje týkající se jednotlivých vodních útvarů (stav, antropogenní vlivy a dopady), chráněných území, monitorovacích objektů a navržených opatření k dosažení environmentálních cílů, a část textovou popisující zejména uplatněné metodické postupy. Součástí reportingu jsou rovněž datové sady geografických údajü: hranic oblastí povodí, vodních útvarů (včetně struktury říční sítě u útvarů povrchových vod), chráněných území s vazbou na vodu a míst monitoringu. Oba výše uvedené pokyny pro reporting kladou vysoké nároky na kvalitu reportovaných informací: přesnost a topologickou konzistenci geografických dat a logickou spojitost a úplnost popisných údajů. Při odesílání na príslušné datové úložiště [7] je kvalita dat automaticky kontrolována a prijiaty jsou pouze dostatečně přesné, konzistentní a úplné údaje. Pokud členský stát některé z požadovaných údajů nemá k dispozici, musí tuto skutečnost předem zdůvodnit.
Přípravou reportingu pověřilo Ministerstvo životního prostředí v rámci podpory výkonu státní správy Výzkumný ústav vodohospodářský T. G. Masaryka, v. v. i. Postup zpracování požadovaných údajů byl zhruba následující. Primárním zdrojem reportovaných informací byly národní plány povodí [1-3]. Plánovaná datová šablona národních plánů povodí vycházela z požadavků na reporting 1. plánů povodí v roce 2010, vzhledem k zásadním změnám požadavků na data nemohla být použita. Podkladová data byla tedy $k$ dispozici pouze $v$ účelových pracovních souborech. Z podrobné analýzy požadavků na reporting vyplynula nutnost doplnění dalších dat a informací, které následně poskytly Ministerstvo životního prostředí (MŽP) a Ministerstvo zemědělství (MZe) a jimi pověrené instituce a organizace (státní podniky Povodí, Výzkumný ústav vodohospodáŕskýT. G. Masaryka, veřejná výzkumná instituce (VúVTGM), Agentura ochrany přírody a krajiny České republiky (AOPK), Vodohospodářský rozvoj a výstavba, a. s. (VRV a. s.), Český hydrometeorologický ústav (ČHMÚ) a Biologické centrum AV ČR, v. v. i. Veškerá data byla následně ve VúV TGM zapracována do účelové geodatabáze. Nástroje relační databáze a GIS umožnily kontrolu kvality dat, včetně návaznosti na předchozí reporting plánů povodí v roce 2010 a návaznosti na reporting podle jiných směrnic. Obsah reportingu byl zapracován do pracovní zprávy a její podrobné datové př́lohy. Součástí zprávy byly souhrnné statistiky a prehledové mapy. Po schválení obsahu reportingu kompetentními úřady, tj. Ministerstvem životního prostředí a Ministerstvem zemědělství, byly informace a data převedeny do požadované struktury a formátu a odeslány na datové úložiště [7].

\section{VÝSLEDKY}

Dále uváděné souhrnné výsledky byly zpracovány v rámci prípravy reportingu plánů povodí a jsou zaměřeny na klíčové kroky týkající se dosažení cílů RSV, tj. charakterizaci povodí, identifikaci antropogenních vlivů a posouzení jejich dopadů na stav vod, vyhodnocení stavu vod a opatření k dosažení environmentálních cílů, popř. stanovení a odůvodnění výjimek.

\section{Charakterizace povodí}

Charakterizace povodí představuje základní etapu plánovacího cyklu a zahrnuje zejména (revizi) vymezení vodních útvarů a chráněných oblastí s vazbou na vodu a identifikaci antropogenních vlivů na stav vod. Jak vodní útvary, tak chráněné oblasti jsou základními jednotkami, pro které je hodnoceno dosažení príslušných environmentálních cílů. Dưležitou součástí vymezení útvarư povrchových vod je určení jejich kategorie a typu. Typy vodních útvarů popisují 


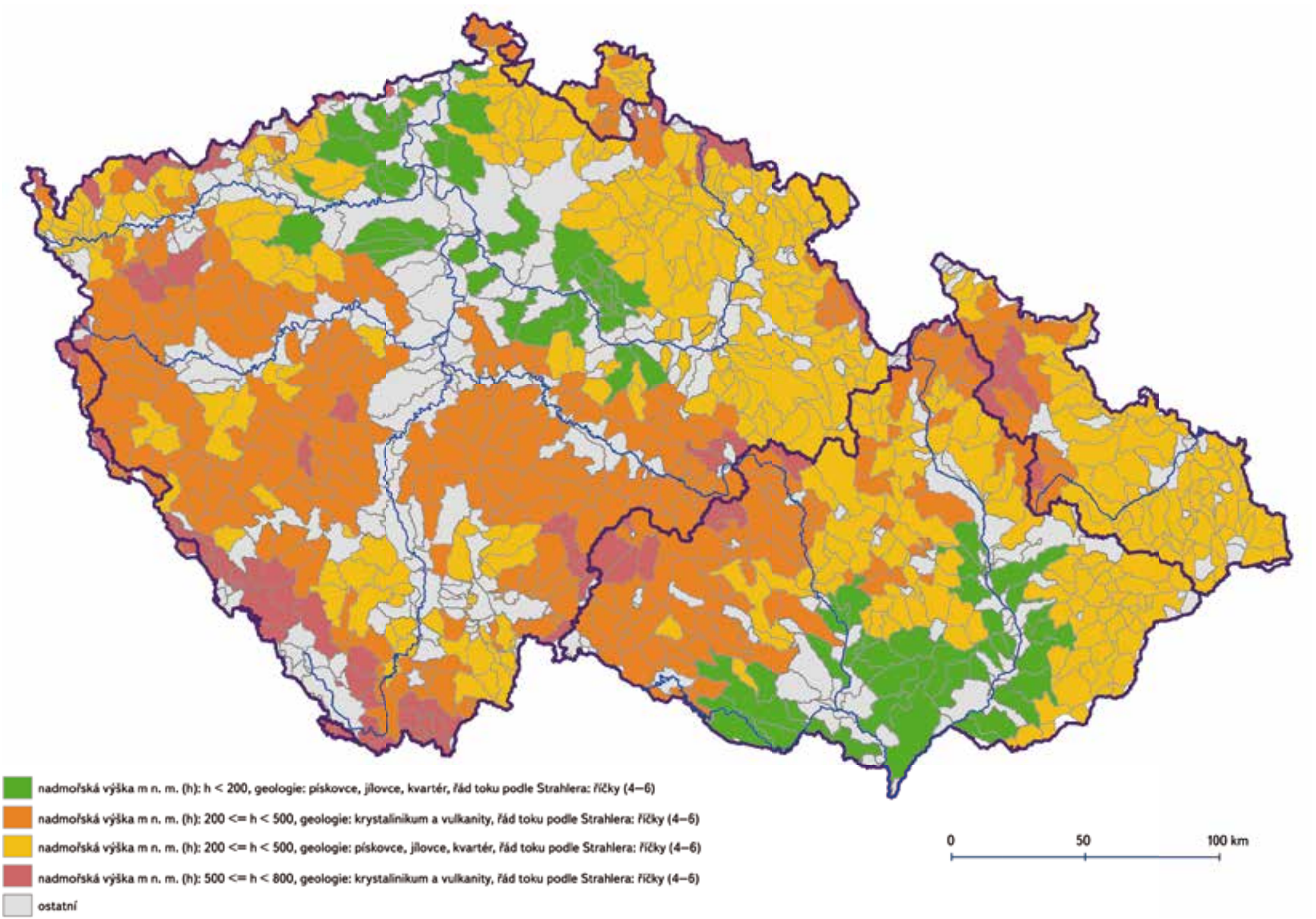

Obr. 1. Typologie útvarů povrchových vod (zdroj dat: MŽP, VúV TGM, Př́rodovědecká fakulta Univerzity Karlovy v Praze)

Fig. 1. Typology of surface water bodies (data source: MoE, TGM WRI, Faculty of Science of the Charles University in Prague)

vybrané abiotické charakteristiky (kategorie nadmořské výšky, geologický typ apod.). Pro každý typ a kategorii útvaru povrchové vody jsou určeny typově specifické (hydromorfologické, fyzikálně-chemické a biologické) referenční podmínky odpovídající velmi dobrému ekologickému stavu, tj. nenarušeným podmínkám. Vzhledem k těmto referenčním podmínkám je hodnocen ekologický stav př́slušného vodního útvaru. Dobrý ekologický stav představuje ještě prípustnou odchylku oproti nenarušenému stavu (referenčním podmínkám). Z důvodu významné změny hydromorfologických charakteristik souvisejících s užitečnými a nenahraditelnými funkcemi útvarů povrchových vod mohou být tyto útvary určeny jako silně ovlivněné nebo umělé. $U$ těchto útvarů je vyžadováno dosažení dobrého ekologického potenciálu. Kategorie a typ útvaru povrchových vod je tak určující pro stanovení příslušných environmentálních cílů (resp. klasifikaci ekologického stavu nebo potenciálu) a hodnocení jejich naplnění.

U útvarů kategorie „řeka“ v Česku určují typ útvaru popisné charakteristiky úmoří, nadmořská výška, geologické podloží a řád toku podle Strahlera. Výrazně převažujícími typy jsou útvary v nadmořské výšce 200 až 500 m n. m. a s řádem toku podle Strahlera 4-6 v závěrném profilu (označované jako říčky), jak je patrné z přehledové mapy na obr. 1. U útvarů kategorie „jezero“ určují typ útvaru

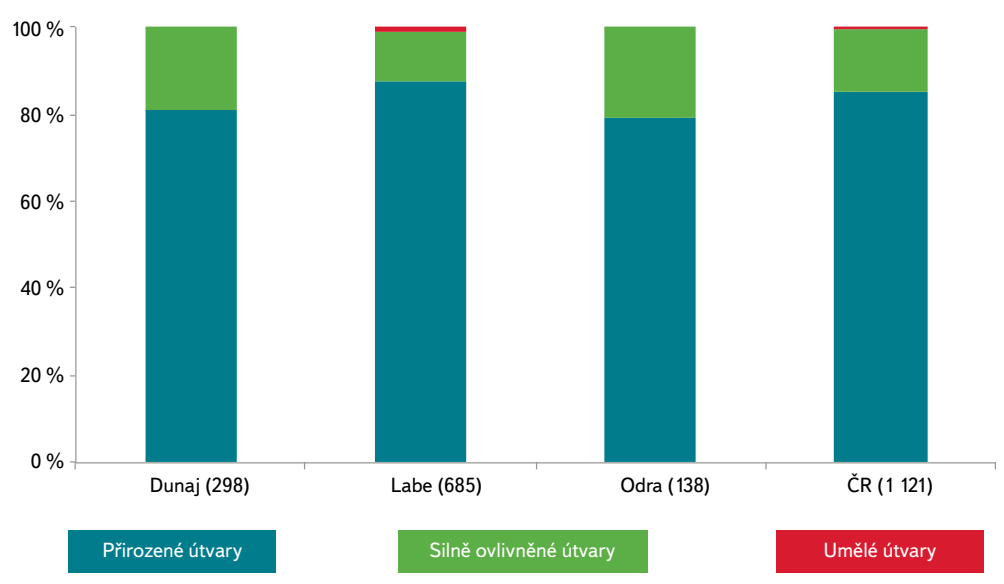

Obr. 2. Kategorie útvarů povrchových vod - podíl počtu útvarů (zdroj dat: MŽP, Vúv TGM, státní podniky Povodí)

Fig. 2. Surface water body categories - percentage of surface water bodies (data source: MoE, TGM WRI, River Boards, s.e.) 


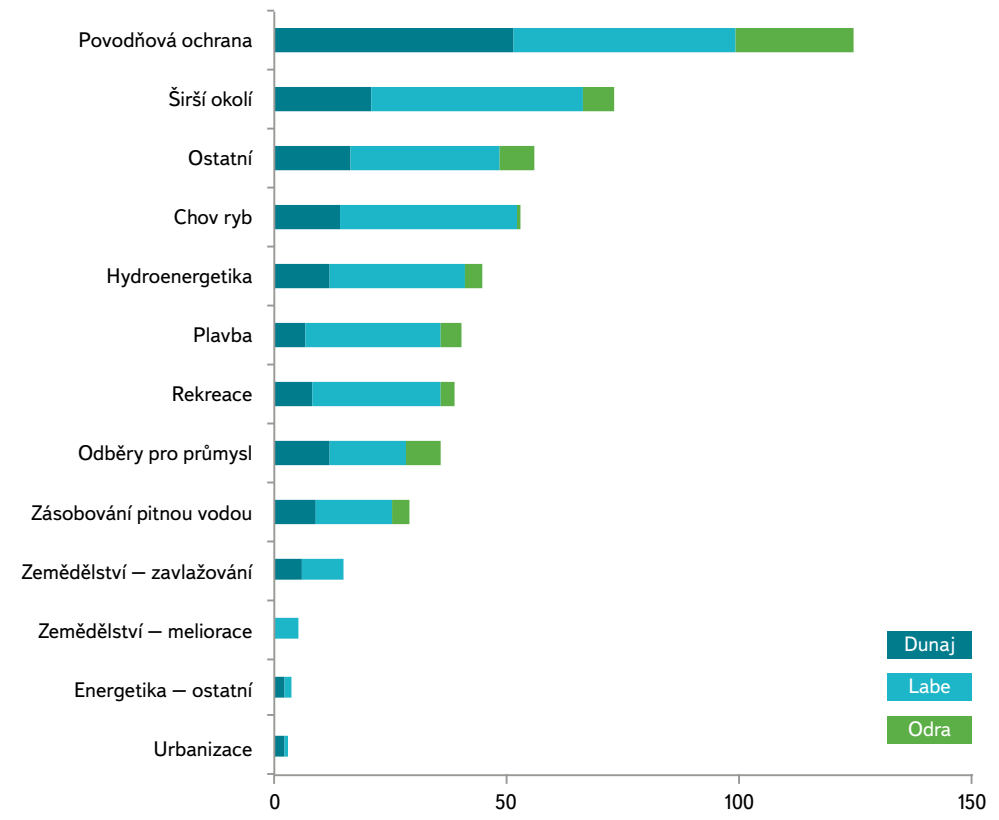

Obr. 3. Užívání vod související se zařazením útvaru do kategorie silně ovlivněných počet útvarů (zdroj dat: státní podniky Povodí)

Fig. 3. Water use - number of heavily modified surface water bodies (data source: River Boards, s.e.)

popisné charakteristiky nadmořská výška, geologické podloží, maximální a průměrná hloubka vody a doba zdržení. Oproti 1. plánovacímu cyklu byla typologie významně pozměněna a v návaznosti rovněž upraveno vymezení cca 30 \% útvarů povrchových vod, zejména v kategorii „řeka“. Celkově bylo v Česku pro 2. plánovací cyklus vymezeno 1044 útvarů v kategorii "řeka“ (z toho 89 silně ovlivněných a 4 umělé) a 77 útvarů v kategorii "jezero" (z toho 73 silně ovlivněných a 4 umělé). Podíl útvarů přirozených, silně ovlivněných a umělých je patrný z grafu na obr. 2. Druhy uživání vod, které byly důvodem pro zařazení útvarů povrchových vod do kategorie silně ovlivněných, jsou uvedeny v grafu na obr. 3. K jednomu vodnímu útvaru bylo většinou přiřazeno více užívání.

Kromě vymezení vodních útvarů RSV rovněž vyžaduje vytvoření a vedení registru všech chráněných oblastí s vazbou na vodu, které byly podle príslušných právních předpisů EU na ochranu povrchových a podzemních vod nebo na zachování stanovišt a druhů živočichů a rostlin přímo závislých na vodě vymezeny jako oblasti vyžadující zvláštní ochranu (tzv. chráněné oblasti s vazbou na vodu). V Česku registr zahrnuje následující druhy chráněných oblastí: území (vodní útvary) vyhrazená pro odběr vody pro lidskou spotřebu, území vyhrazená jako rekreační vody a vody ke koupání (koupací oblasti), území citlivá na živiny (zranitelné oblasti), území vyhrazená pro ochranu stanovišt a druhů (výběr ptačích oblastí a evropsky významných lokalit) a dále specificky pro česko-ramsarské mokřady a výběr maloplošných zvláště chráněných území s vazbou na vodu. Mezipovodí útvarů povrchových vod s odběry vody pro lidskou spotřebu a výběr ptačích oblastí a evropsky významných lokalit s vazbou na vodu jsou zobrazeny na přehledových mapách na obr. 4 a 5.

Klíčovou etapou plánovacího cyklu je zhodnocení dopadů lidské činnosti na stav vod. Analýza dopadů lidské činnosti vychází z konceptu DPSIR (Driver-Pressure-State-Impact-Response). Identifikace vlivů a vyhodnocení dopadů na jednotlivé vodní útvary je nezbytným předpokladem pro určení vodních útvarů rizikových z hlediska dosažení environmentálních cílů, nastavení programů monitoringu a zejména návrh opatření či stanovení a odůvodnění výjimek z dosažení cílů. Za významné antropogenní vlivy jsou považovány ty, které samy o sobě nebo ve spojení s jinými vlivy přispívají k nepříznivému dopadu na stav vod a brání tak nebo ohrožují dosažení stanovených environmentálních

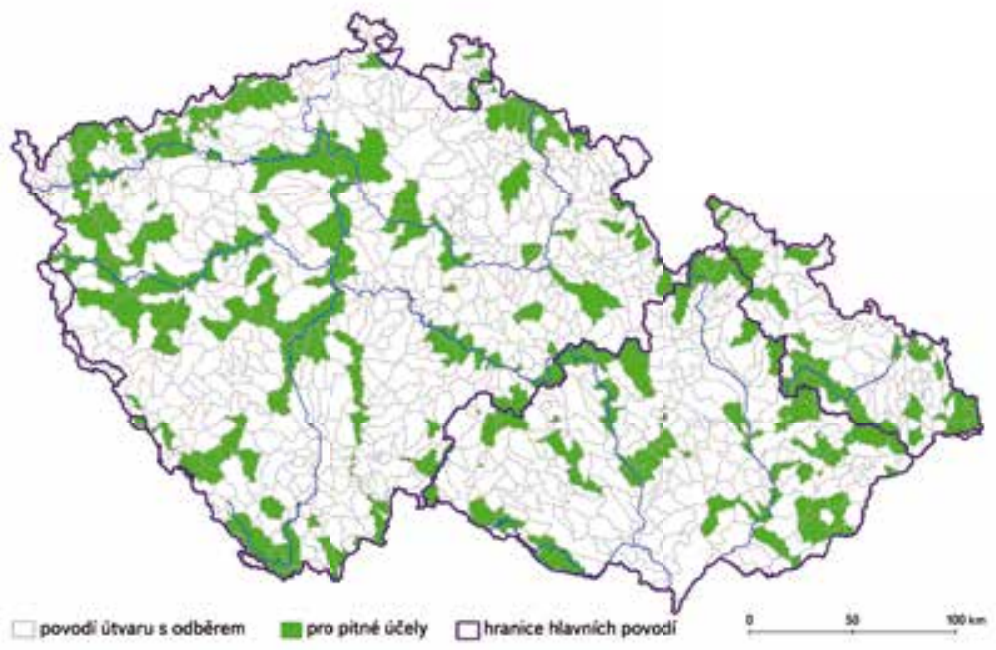

Obr. 4. Mezipovodí útvarů povrchových vod s odběrem pro lidskou spotřebu (zdroj dat: VúV TGM, státní podniky Povodí)

Fig. 4. Basin of surface water bodies with abstraction for drinking water (data source: TGM WRI, River Boards, s.e.)

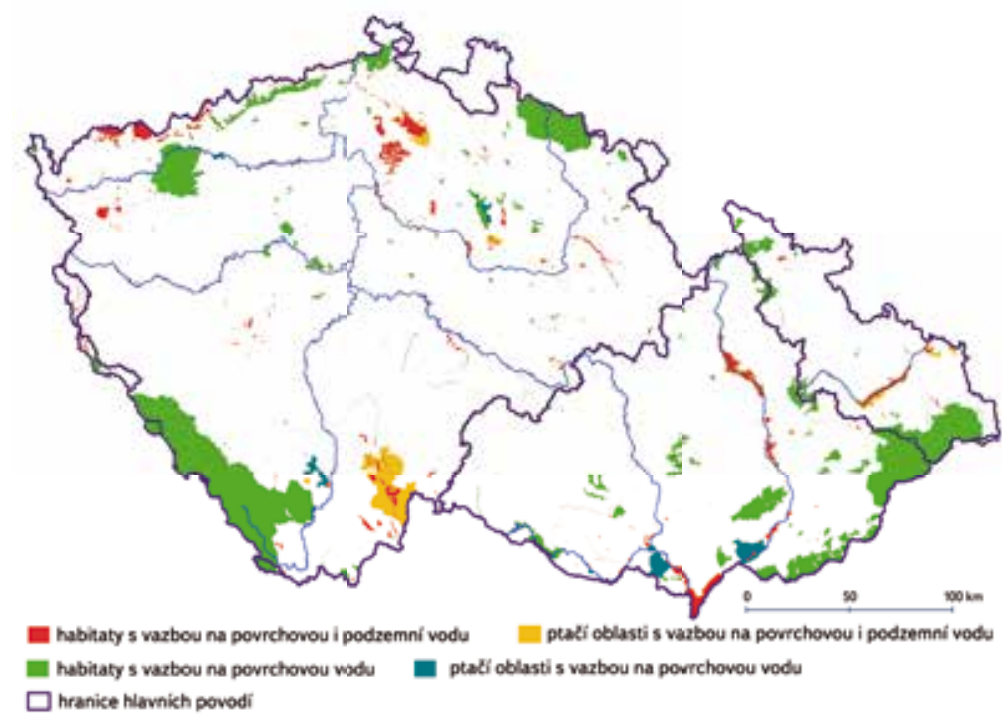

Obr. 5. Habitaty a ptačí oblasti s vazbou na vodu (zdroj dat: AOPK, VúV TGM) Fig. 5. Protected areas - habitats and birds, directly depedent on water (data source: AOPK, TGM WRI)

cílů (viz dále). V Česku byly (z důvodu předběžné opatrnosti) významné vlivy identifikovány i ve vodních útvarech, ve kterých se předpokládá dosažení dobrého stavu ke konci 1. plánovacího cyklu roku 2015. U útvarů, kde není předpokládáno dosažení dobrého stavu či potenciálu ke konci 1. plánovacího cyklu $\checkmark$ roce 2015 , byly vlivy vztaženy k jednotlivým složkám kvality a ukazatelům (látkám), které byly pro dosažení dobrého stavu vyhodnoceny jako problémové. Četnost skupin (typů) v Česku identifikovaných významných vlivů je uvedena v grafu na obr. 6. Poměrně vysoký počet neznámých vlivů se převážně vztahuje k určitým (zejména biologickým) složkám kvality či látkám, nikoli k vodním útvarům jako celku. 


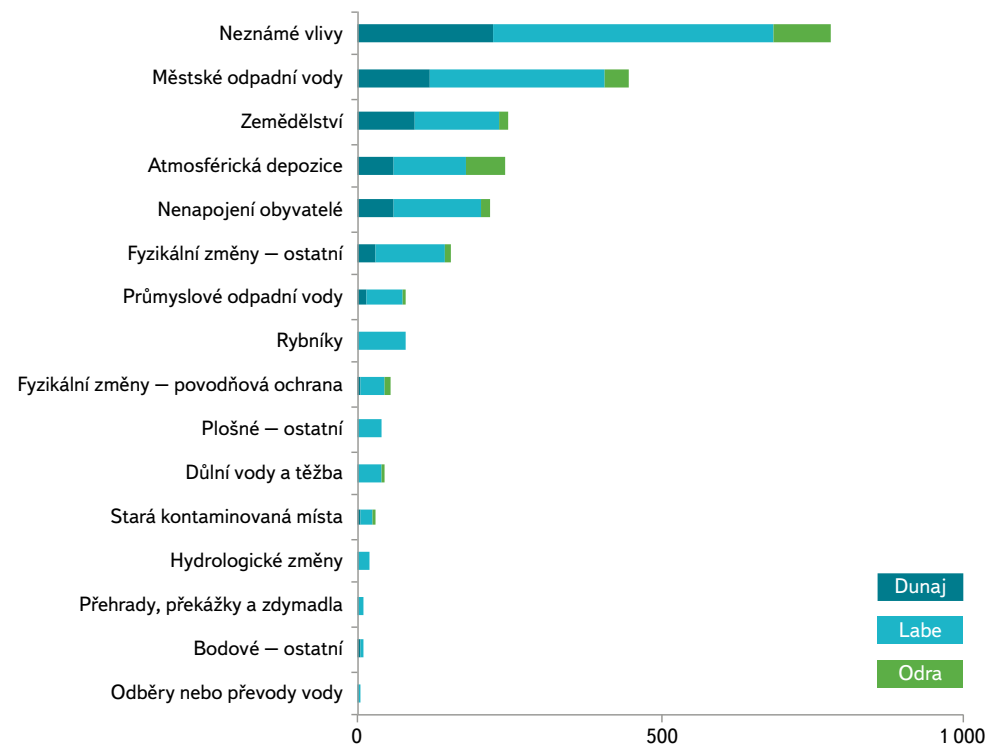

Obr. 6. Vlivy na útvary povrchových vod - počet útvarů (zdroj dat: státní podniky Povodí, VRV a. s.)

Fig. 6. Pressures on surface water bodies - number of surface bodies (data source: River Boards, s.e., VRV a. s.)

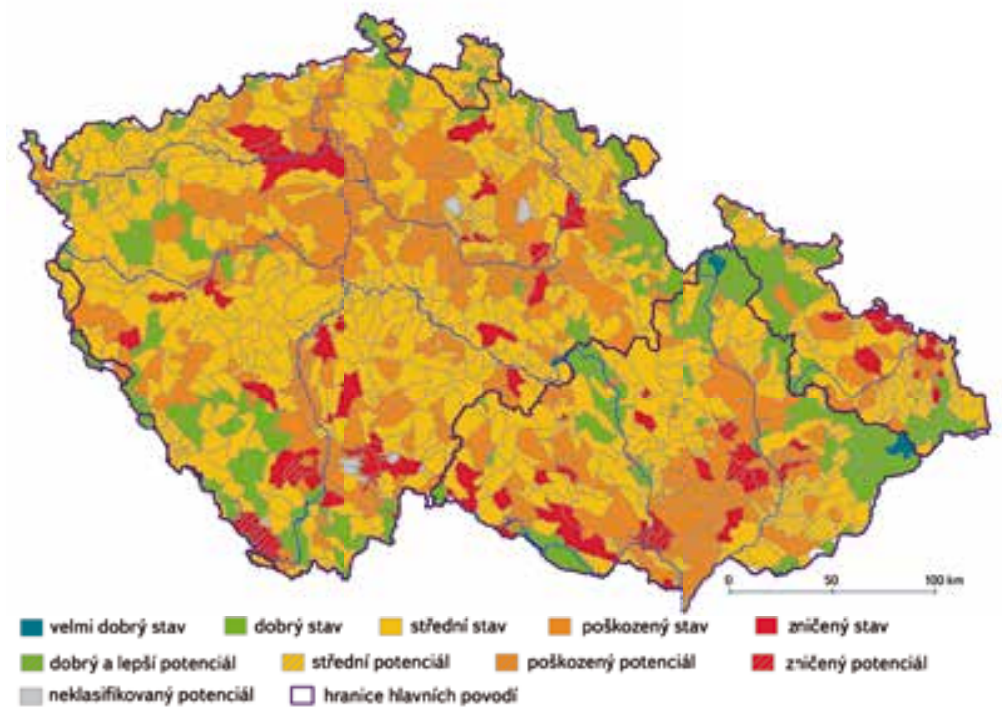

Obr. 7. Ekologický stav nebo potenciál útvarů povrchových vod (zdroj dat: MŽP, VúV TGM, Biologické centrum AV ČR, státní podniky Povodí)

Fig. 7. Ecological status or potential of surface water bodies (data source: MoE, TGM WRI, Biology Centre CAS, River Boards, s.e.)

\section{Environmentální cíle a výjimky}

Mezi environmentální cíle specifikované RSV patři dosažení dobrého stavu vodních útvarů (popř. dobrého potenciálu útvarů silně ovlivněných a umělých), nezhoršování stavu, zamezení nebo omezení vstupů znečištujuících látek do podzemních vod a zvrácení prípadného trvale vzestupného trendu koncentrace znečištujuící látky $v$ podzemních vodách $v$ důsledku lidské činnosti. Dobrý kvantitativní, chemický a ekologický stav či potenciál vodních útvarů a cíle ochrany chráněných oblastí s vazbou na vodu mají být dosaženy do roku 2015. RSV zároveň umožňuje za určitých podmínek následující výjimky

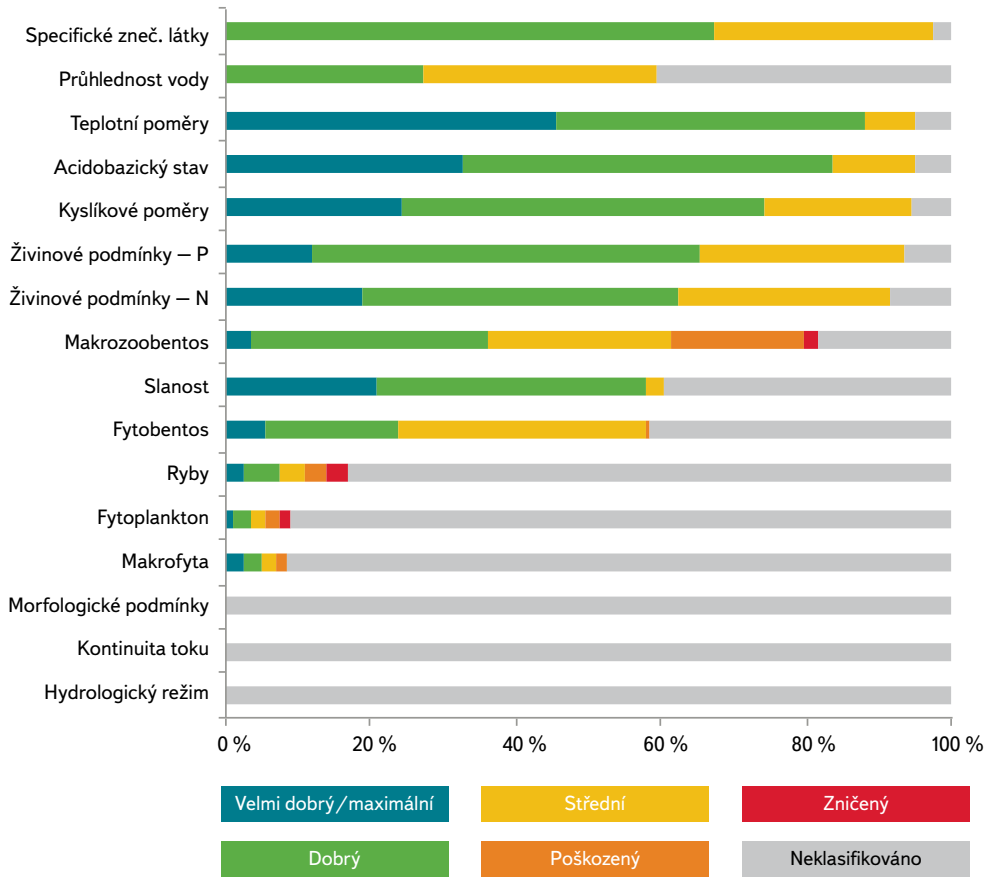

Obr. 8. Složky ekologického stavu nebo potenciálu povrchových vod - podíl počtu útvarů (zdroj dat: MŽP, VÚV TGM, Biologické centrum AV ČR, státní podniky Povodí) Fig. 8. Quality elements of ecological status/potential - percentage of surface water bodies (data source: MoE, TGM WRI, Biology Centre CAS, River Boards, s.e.)

z dosažení uvedených obecných cílů: prodloužení lhưty na dobu po roce 2015 nebo dosažení méně přísných cílů z důvodu technické proveditelnosti, neúměrných nákladů nebo přírodních podmínek. Výjimky z dosažení cílů Ize aplikovat i při výskytu mimořádných událostí. RSV za určitých podmínek připouští rovněž zhoršení stavu nebo nedosažení určitých environmentálních cílů u nových změn fyzických charakteristik útvarů povrchových vod způsobených rozvojovou činností člověka. Na základě návrhů opatření a stanovených výjimek z dosažení dobrého stavu vodních útvarů k roku 2015 je rovněž vyhodnocen předpokládaný termín dosažení dobrého stavu.

Vyhodnocení stavu vodních útvarů plní v plánovacím cyklu dvojí účel:

A. na začátku plánovacího cyklu umožňuje identifikovat vodní útvary, kde je ohroženo splnění požadovaných environmentálních cílů ( $v$ prípadě povrchových vod dosažení dobrého chemického a ekologického stavu vodních útvarů, v případě podzemních vod dosažení dobrého kvantitativního a chemického stavu útvarů) a následně tam, kde je třeba, navrhnout a realizovat př̌slušná opatření (popř. specifikovat nezbytné výjimky z dosažení cílů),

B. na konci plánovacího cyklu umožňuje posoudit, zda bylo plánovaných environmentálních cílů dosaženo (tj. například zda přislušná opatření měla předpokládaný efekt).

Ekologický stav útvarů povrchových vod se hodnotí porovnáním současného stavu s blízkými prírodními nebo referenčními podmínkami. Ekologický stav útvaru určuje jeho nejhůře hodnocená složka kvality. V Česku byl hodnocen podle údajů z monitoringu převážně za období let 2010 až 2012. Hodnoceny nebyly hydromorfologické složky kvality. Vyhodnocení ekologického stavu nebo potenciálu je patrné na prehledové mapě na obr. 7. Dílčí hodnocení jednotlivých složek kvality a rozsah jejich monitoringu jsou znázorněny grafem na obr. 8. Vzhledem ke změnám ve vymezení útvarů povrchových vod a změnám $v$ postupech hodnocení nebylo možné porovnat výsledky hodnocení 


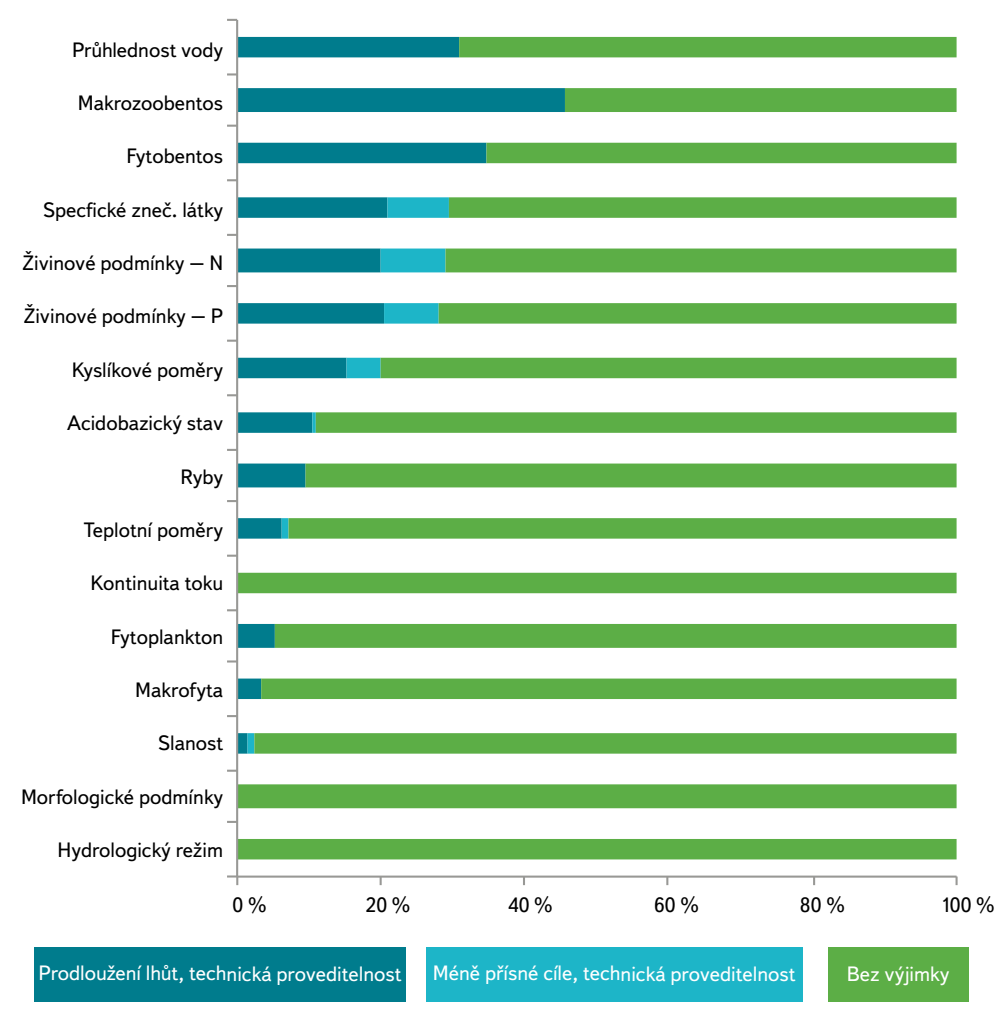

Obr. 9. Výjimky z dobrého ekologického stavu nebo potenciálu - podíl počtu útvarů (zdroj dat: MZe, VRV a. s.)

Fig. 9. Exemptions of good ecological status/potential - percentage of surface water bodies (data source: MoA, VRV a. s.)

ekologického stavu v 1. a 2. plánech povodí. Pro dosažení dobrého chemického stavu jsou v plánech uplatněny jako výjimky prodloužení lhůt a méně přísné cíle $z$ důvodu technické proveditelnosti. Výjimky jsou u jednotlivých vodních útvarů vztaženy jak k jednotlivým složkám kvality, tak k typům antropogenních vlivů. Rozsah výjimek pro složky kvality je uveden v grafu na obr. 9. Předpokládaný termín dosažení dobrého ekologického stavu útvarů povrchových vod je uveden na přehledové mapě na obr. 10.

Dosažení dobrého chemického stavu útvarů povrchových vyžaduje plnění príslušných norem environmentální kvality pro prioritní látky. Kromě nepřekročení stanovené limitní koncentrace látek v povrchových vodách je u některých látek vyžadováno sledování trendů koncentrací v biotě nebo sedimentu. Chemický stav útvarů povrchových vod byl hodnocen podle dat z monitoringu převážně za období let 2010 až 2012. Vyhodnocení chemického stavu je patrné na přehledové mapě na obr. 11. Na grafu na obr. 12 jsou uvedeny látky, které jsou nejčastější přičinou nedosažení dobrého chemického stavu a rozsahu jejich monitoringu. Zatímco pro zpracování 1. plánů povodí byl chemický stav hodnocen podle požadavků (v té době platné) směrnice 2008/105/ES, pro 2. plánovací cyklus byl stav vyhodnocen pro požadavky zpřísněné směrnicí 2013/39/EU [8]. Pro potřeby reportingu a vyhodnocení pokroku byl stav monitorovaný v letech 2010 až 2012 dodatečně vyhodnocen rovněž podle směrnice 2008/105/ES. Zlepšení či zhoršení stavu pro vybrané prioritní látky je patrné z grafu na obr. 13, spolehlivost porovnání je nicméně limitována změnami v monitorovacích programech. Součástí reportingu byla rovněž identifikace vodních útvarů a látek, u kterých dosažení dobrého chemického stavu zabránilo zpřísnění limitu podle směrnice 2013/39/EU. V Česku se nejčastěji jednalo o fluoranten (233 útvarů),

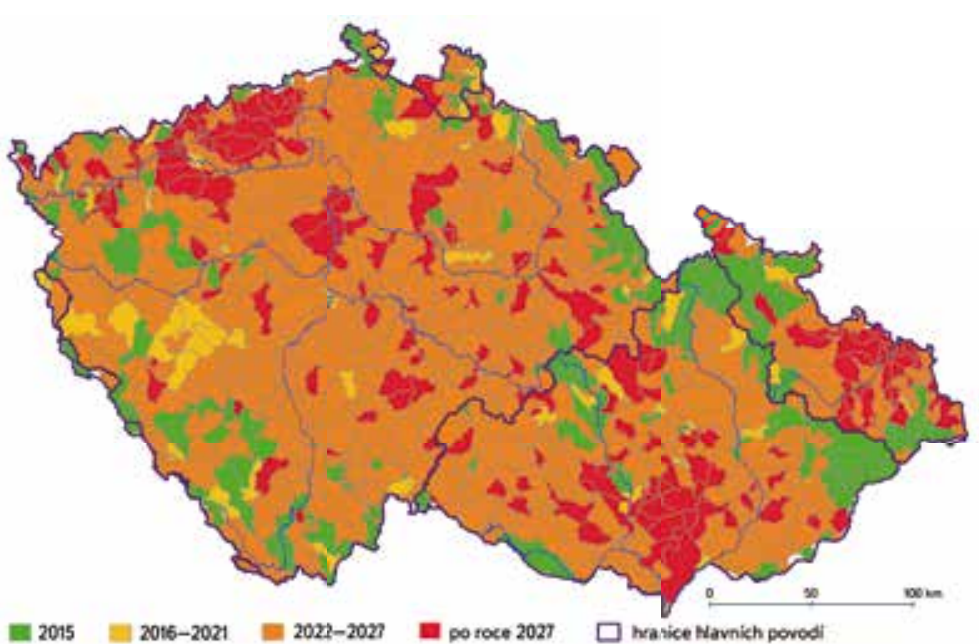

Obr. 10. Dosažení dobrého ekologického stavu nebo potenciálu útvarů povrchových vod (zdroj dat: MZe, VRV a. s.)

Fig. 10. Good ecological status/potential expected achievement date (data source: MoA, VRV a. s.)

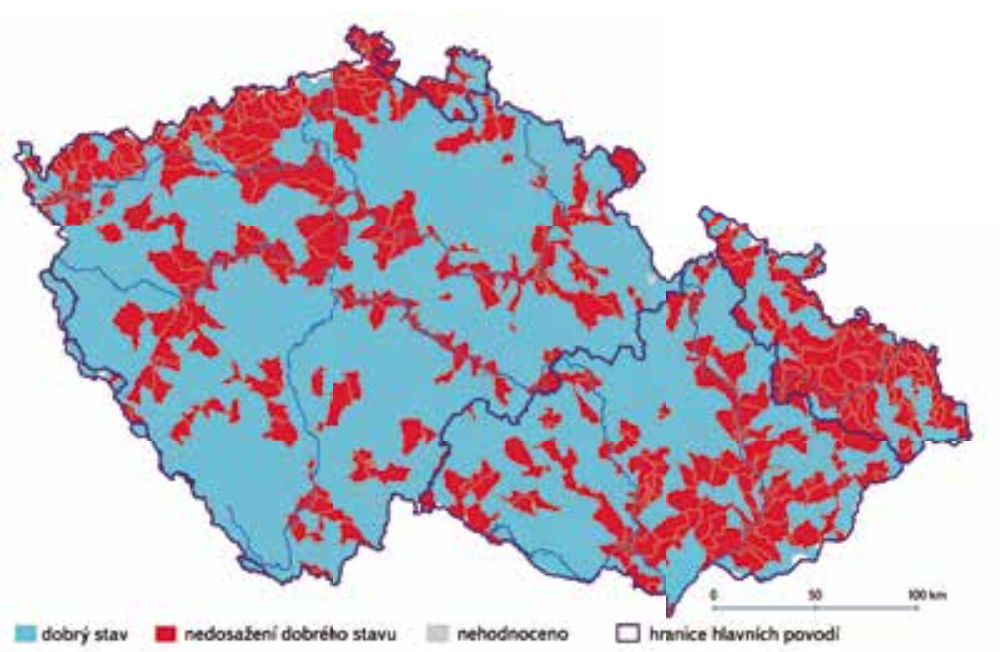

Obr. 11. Chemický stav útvarů povrchových vod (zdroj dat: MŽP, VúV TGM, státní podniky Povodí)

Fig. 11. Chemical status of surface water bodies (data source: MoE, TGM WRI, River Boards, s.e.)

nikl (169) a benzo(a)pyren (167). Pro dosažení dobrého chemického stavu jsou v plánech uplatněny jako výjimky prodloužení lhůt a méně přísné cíle z důvodu technické proveditelnosti. Výjimky jsou u jednotlivých vodních útvarů vztaženy jak k jednotlivým prioritním látkám, tak k typům antropogenních vlivů. Rozsah výjimek pro nejproblémovější prioritní látky je uveden v grafu na obr. 14. Předpokládaný termín dosažení dobrého chemického stavu útvarů povrchových vod je uveden na přehledové mapě na obr. 15. 


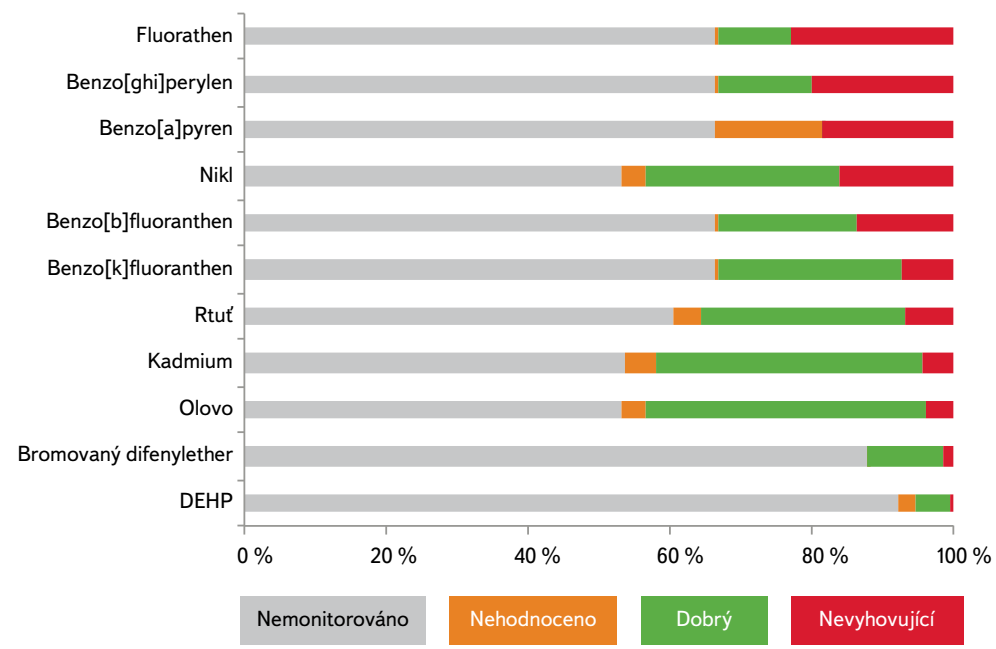

Obr. 12. Chemický stav povrchových vod - nejčastěji nevyhovující ukazatele - podíl počtu útvarů (zdroj dat: MŽP, VúV TGM, státní podniky Povodí)

Fig. 12. Chemical status of surface water - most frequent pollutants causing less than good status - percentage of surface water bodies (data source: MoE, TGM WRI, River Boards, s.e.)

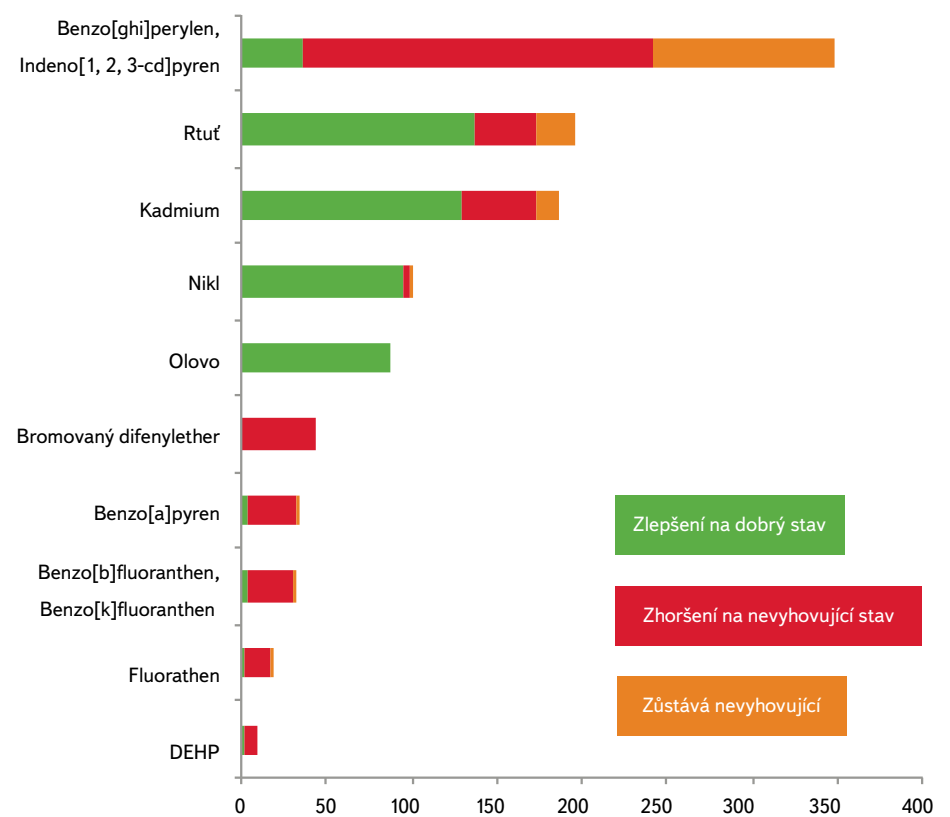

Obr. 13. Změna chemického stavu podle směrnice 2008/105/ES - vybrané ukazatele počet útvarů (zdroj dat: MŽP, VÚV TGM, státní podniky Povodí)

Fig. 13. Change of chemical status according to Directive 2008/105/ES - selected pollutants - number of surface water bodies (data source: MoE, TGM WRI, River Boards, s.e.)

Kvantitativní stav útvarů podzemních vod je v Česku hodnocen jako bilance uskutečněných odběrů (pro 2. plány za období 2007 až 2012) a dostupných zdrojů podzemních vod reprezentovaných jako dlouhodobé roční průměrné množství celkového doplňování vodního útvaru. Zohledněno je prípadné negativní ovlivnění ekologického stavu souvisejících povrchových vod a terestrických ekosystémů. Hodnocení kvantitativního stavu pro 2. plány povodí je patrné z přehledové mapy na obr. 16, pokrok v dosažení dobrého kvantitativního stavu oproti vyhodnocení pro 1. plány povodí z prehledové mapy na obr. 17.

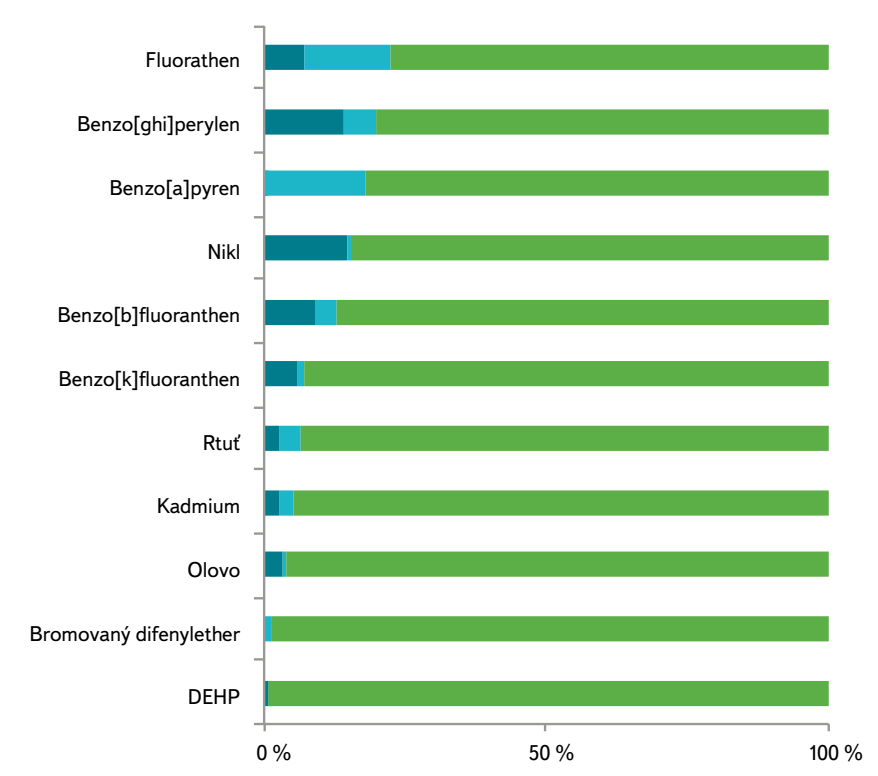

Prodlouženi hử, technická proveditelnos

Obr. 14. Výjimky z dobrého chemického stavu povrchových vod - podíl počtu útvarů (zdroj dat: MZe, VRV a. s.)

Fig. 14. Exemptions of good chemical status of surface water - percentage of surface water bodies (data source: MoA, VRV a. s.)

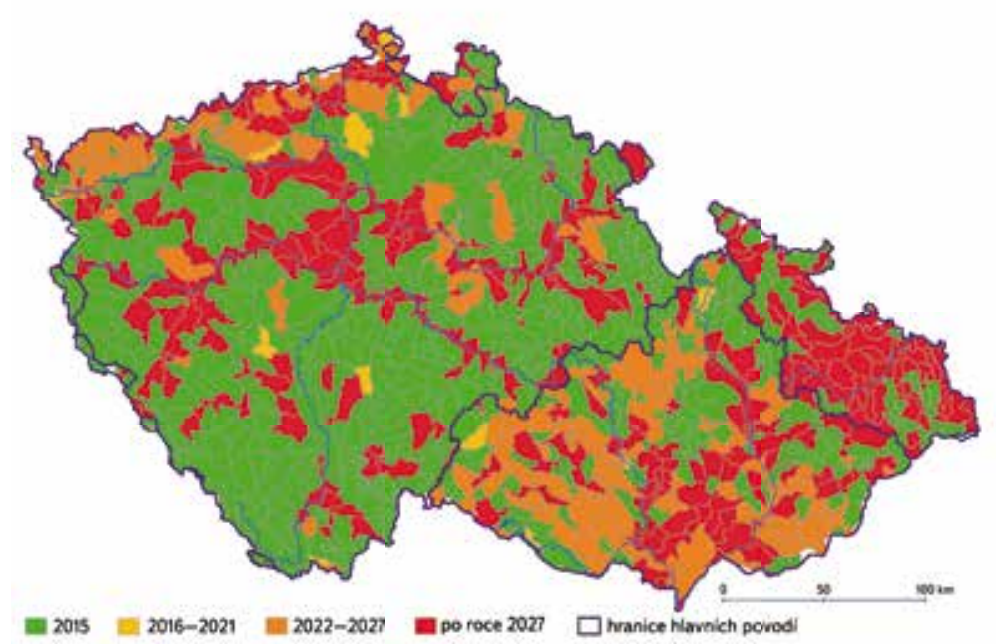

Obr. 15. Dosažení dobrého chemického stavu povrchových vod (zdroj dat: MZe, VRV a. s.) Fig. 15. Good chemical status expected achievement date (data source: MoA, VRV a. s.)

Pro dosažení dobrého kvantitativního stavu jsou v plánech uplatněny jako výjimky prodloužení lhůt z důvodu prírodních podmínek i technické proveditelnosti a méně prísné cíle z důvodu technické proveditelnosti. Rozsah výjimek je uveden v grafu na obr. 18. Předpokládaný termín dosažení dobrého kvantitativního stavu útvarů podzemních vod je uveden na prehledové mapě na obr. 19. 


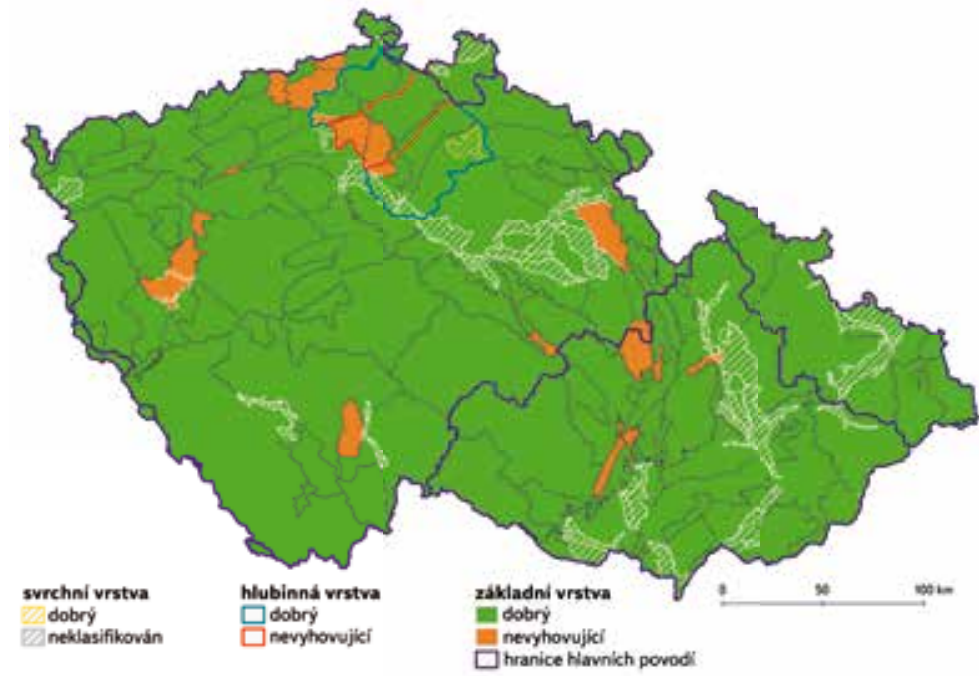

Obr. 16. Kvantitativní stav podzemních vod (zdroj: MŽP, VúV TGM, státní podniky Povodí) Fig. 16. Quantitative status of groundwater bodies (source: MoE, TGM WRI, River Boards, s.e.)

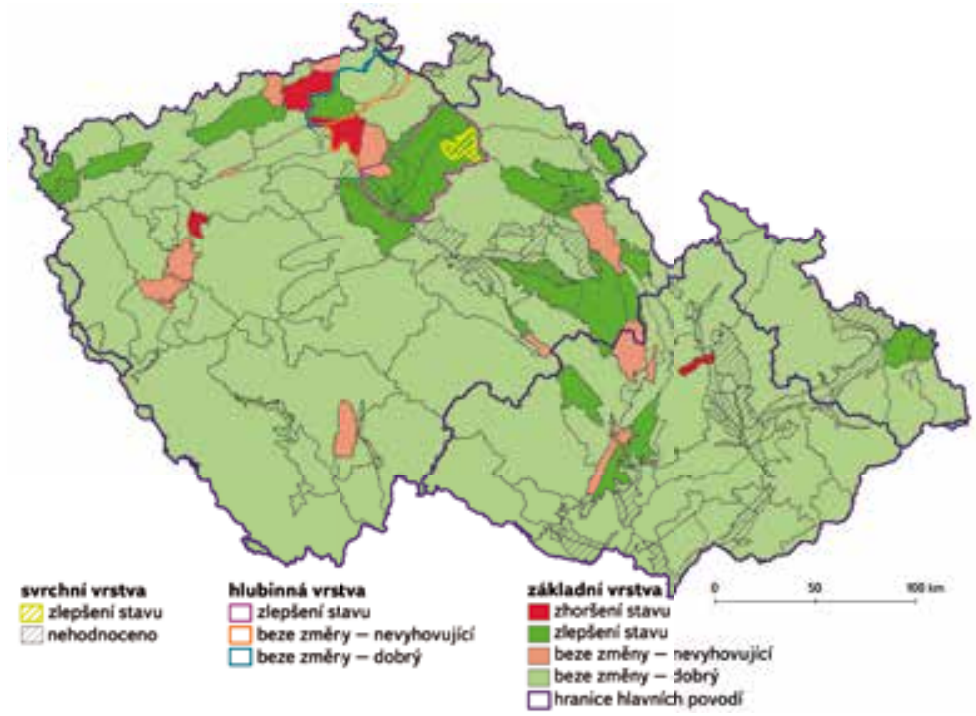

Obr. 17. Změny kvantitativního stavu podzemních vod mezi 1. a 2. plánovacím cyklem (zdroj: MŽP, VÚV TGM, státní podniky Povodí)

Fig. 17. Changes in quantitative status of groundwater bodies between $1^{\text {st }}$ and $2^{\text {nd }}$ planning cycle (source: MoE, TGM WRI, River Boards, s.e.)

Chemický stav útvarů podzemních vod byl hodnocen podle údajů z monitoringu za období let 2000 až 2012. Každá látka byla monitorována nejméně v 98 \% vodních útvarů. Zohledněn byl rovněž prípadný nepříznivý dopad na stav útvarů povrchových vod (pro dusičnany a amonné ionty) a hodnoty přirozeného pozadí látek v podzemních vodách. Významný a setrvalý vzestupný trend $v$ koncentracích znečištujujicích látek byl nejčastěji zaznamenán u niklu (7 útvarů), hliníku (6) a arsenu (5). Vyhodnocení chemického stavu je patrné na přehledové mapě na obr. 20, pokrok v dosažení dobrého chemického stavu oproti vyhodnocení pro 1. plány povodí z přehledové mapy na obr. 21. V grafu

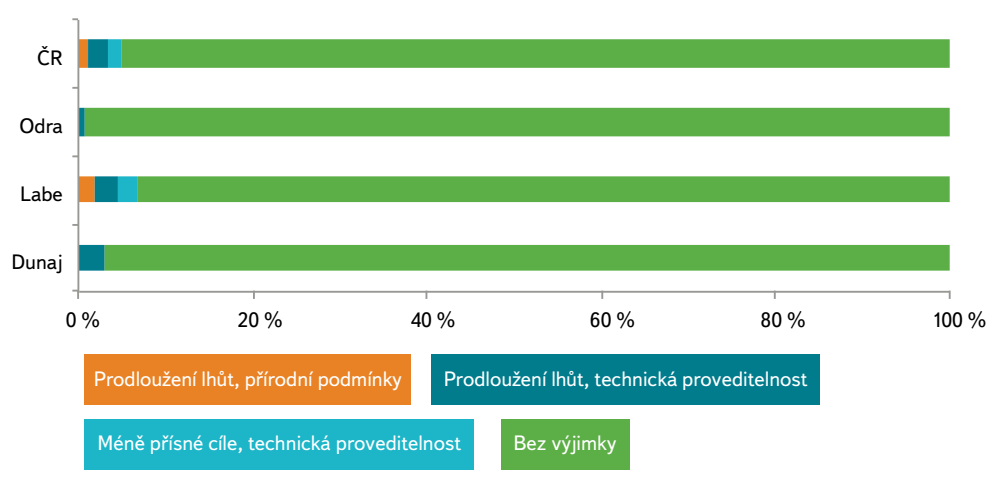

Obr. 18. Výjimky z dobrého kvantitativního stavu podzemních vod - podíl plochy útvarů (zdroj dat: MZe, VúV TGM)

Fig. 18. Exemptions of good quantitative status of groundwater - percentage of groundwater bodies area (data source: MoA, TGM WRI)

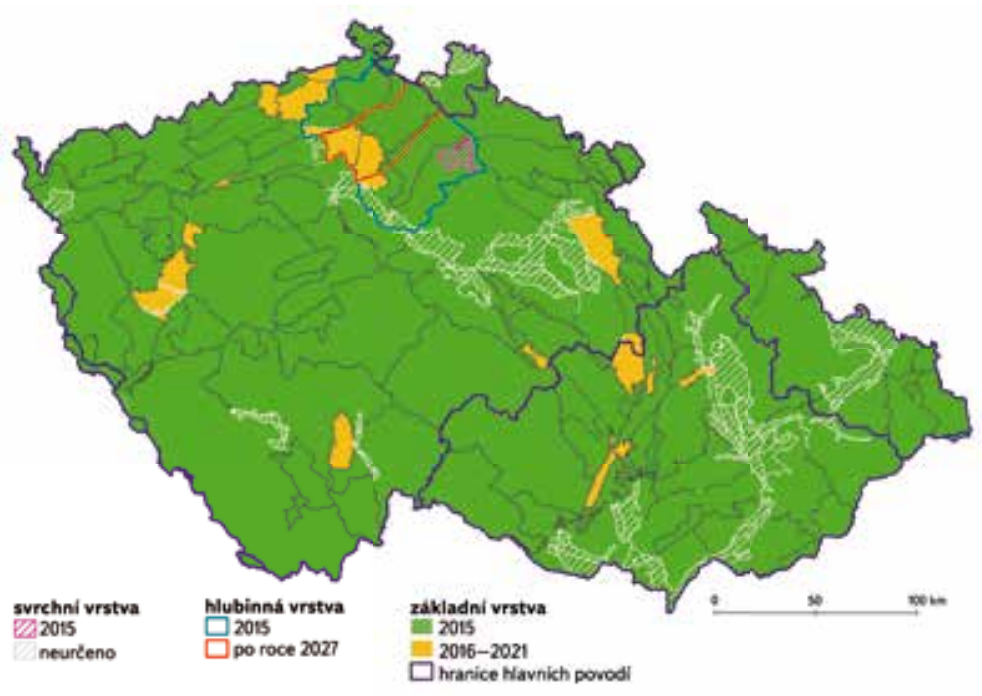

Obr. 19. Dosažení dobrého kvantitativního stavu podzemních vod (zdroj dat: MZe, VÚVTGM) Fig. 19. Good quantitative status expected achievement date (data source: MoA, TGM WRI)

na obr. 22 jsou uvedeny látky, které jsou nejčastější prríčinou nedosažení dobrého chemického stavu. Pro dosažení dobrého chemického stavu jsou v plánech uplatněny jako výjimky prodloužení lhůt z důvodu prírodních podmínek i technické proveditelnosti a méně prísné cíle z důvodu technické proveditelnosti. Výjimky jsou u jednotlivých vodních útvarů vztaženy jak k jednotlivým znečištujícím látkám, tak k typům antropogenních vlivů. Rozsah výjimek je pro vybrané látky uveden v grafu na obr. 23. Předpokládaný termín dosažení dobrého chemického stavu útvarů podzemních vod je uveden na přehledové mapě na obr. 24. 


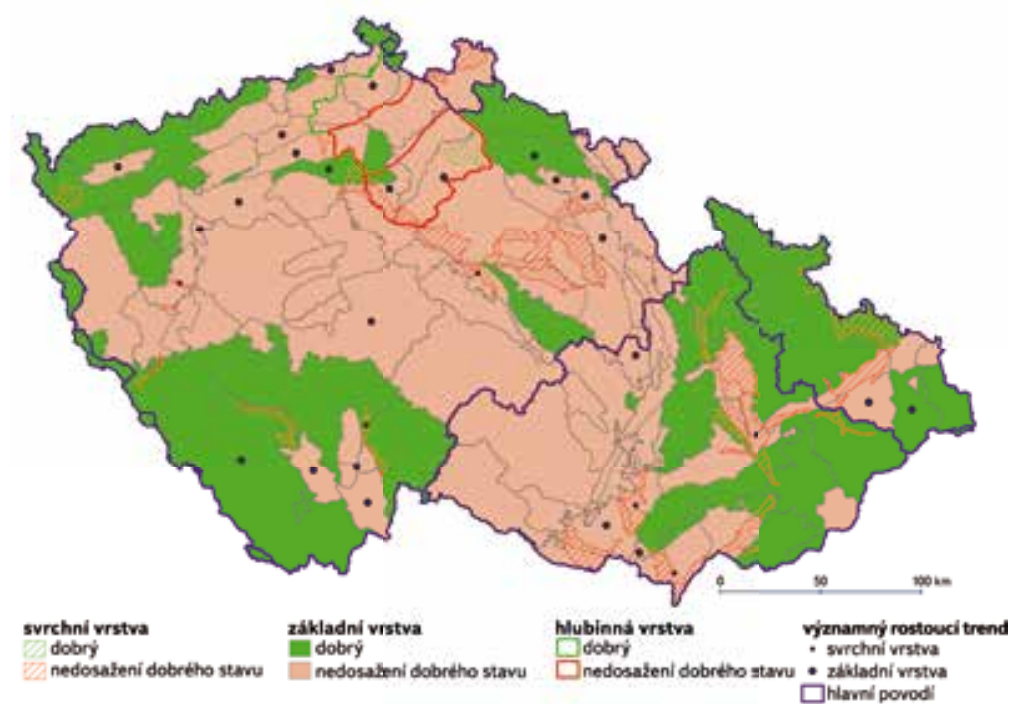

Obr. 20. Chemický stav útvarů podzemních vod a významný a setrvalý vzestupný trend koncentrací znečištujících látek (zdroj dat: MŽP, VúV TGM, ČHMÚ)

Fig. 20. Chemical status of groundwater bodies and significant and sustained upward trend in the concentrations of pollutants (data source: MoE, TGM WRI, CHMI)

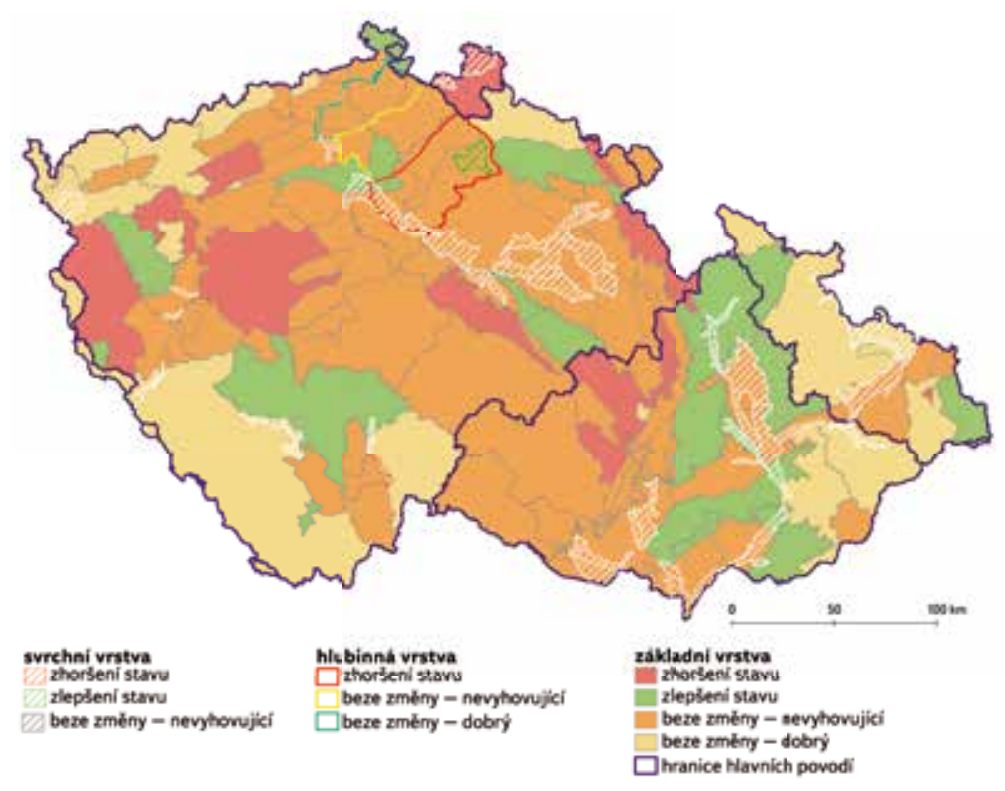

Obr. 21. Změna chemického stavu útvarů podzemních vod mezi 1. a 2. plánovacím cyklem (zdroj dat: MŽP, VúV TGM, ČHMÚ)

Fig. 21. Change of chemical status of groundwater bodies between $1^{\text {st }}$ and $2^{\text {nd }}$ planning cycle (data source: MoE, TGM WRI, CHMI)

\section{Opatření k dosažení environmentálních cílů}

RSV požaduje vypracovat k dosažení environmentálních cílů přislušný program opatření. Pokyn [5] vyžaduje jednotlivá opatření uvedená v plánech povodí sloučit pro účely reportingu do tzv. klíčových typů. V ČR byla opatření navrhována jednak na úrovni dílčích povodí, ta se týkala hlavně konkrétních jednotlivých opatření, a dále na úrovni národních plánů, kde bylo vytvořeno celkem jedenáct opatření pokrývajících problematiku znečištění (hlavně z plošných zdrojů - hnojení, eroze, pesticidy, atmosférická depozice, nebezpečné látky

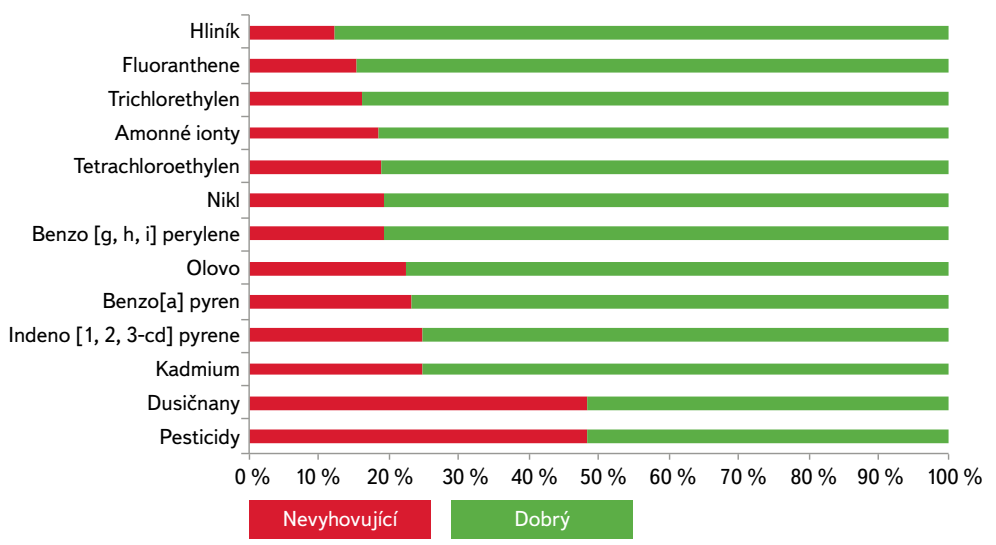

Obr. 22. Chemický stav podzemních vod, vybrané ukazatele - podíl plochy útvarů (zdroj dat: MŽP, VúV TGM, ČHMÚ)

Fig. 22. Groundwater body chemical status - selected pollutants - percentage of groundwater bodies area (data source: MoE, TGM WRI, CHMI)

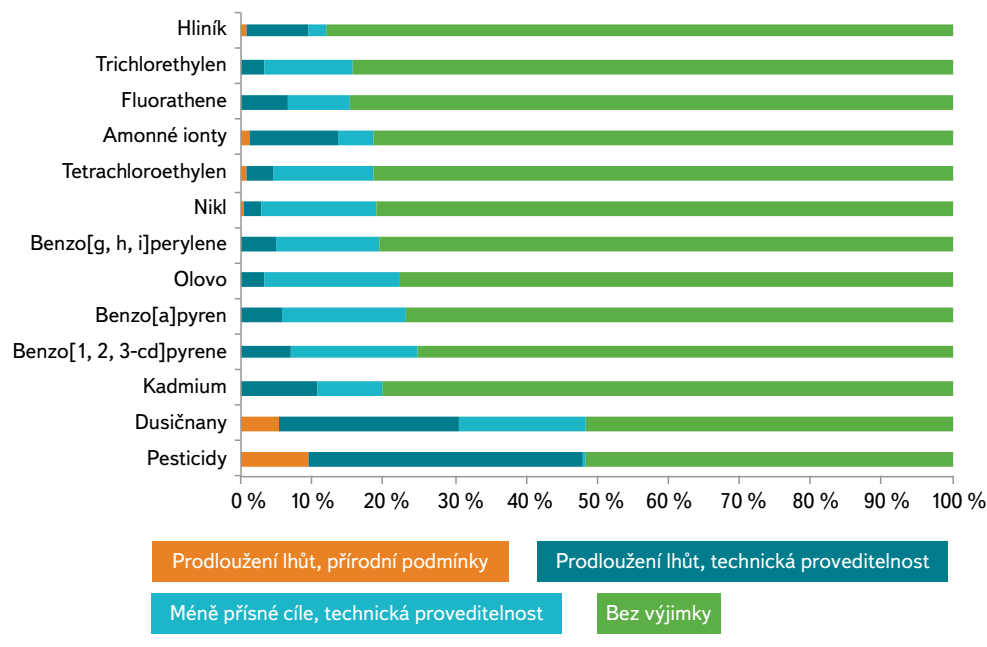

Obr. 23. Výjimky z dobrého chemického stavu podzemních vod - podíl plochy útvarů (zdroj dat: MZe, VúV TGM)

Fig. 23. Exemptions of good chemical status of groundwater - percentage of groundwater bodies area (data source: MoA, TGM WRI)

chov ryb v rybnících), některých aspektů hydromorfologie (zprůchodnění říční sítě, minimální průtoky a obnova prírozených koryt vodní sítě), množství povrchových a podzemních vod (sucho a nedostatek vody, stanovení prírodních zdrojů podzemních vod) a chráněných území (Natura 2000, mokřady a odběry pro lidskou spotřebu). Tato opatření jsou obecnější, stanoví strategie a jednotlivé kroky, které jsou převážně v kompetenci státní správy.

Přehled počtů nejčastějších konkrétních opatření je na obr. 25 ( $v$ jednom útvaru může být navrženo více opatření stejného typu). 


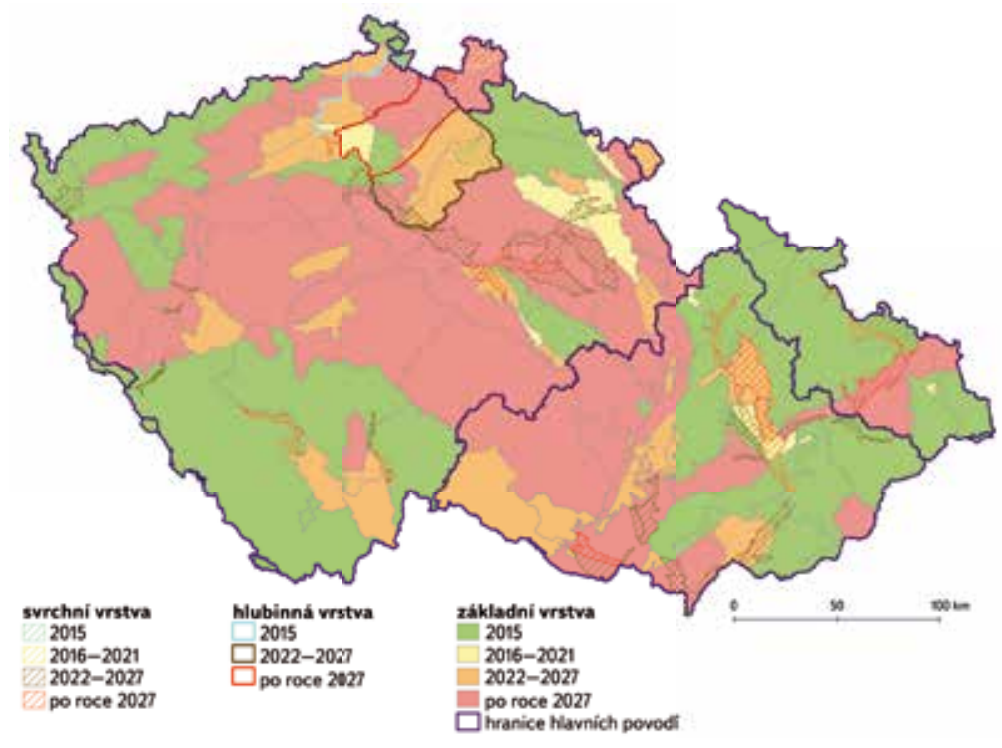

Obr. 24. Dosažení dobrého chemického stavu podzemních vod (zdroj dat: MZe, VúV TGM) Fig. 24. Good chemical status expected achievement date (data source: MoA, TGM WRI)

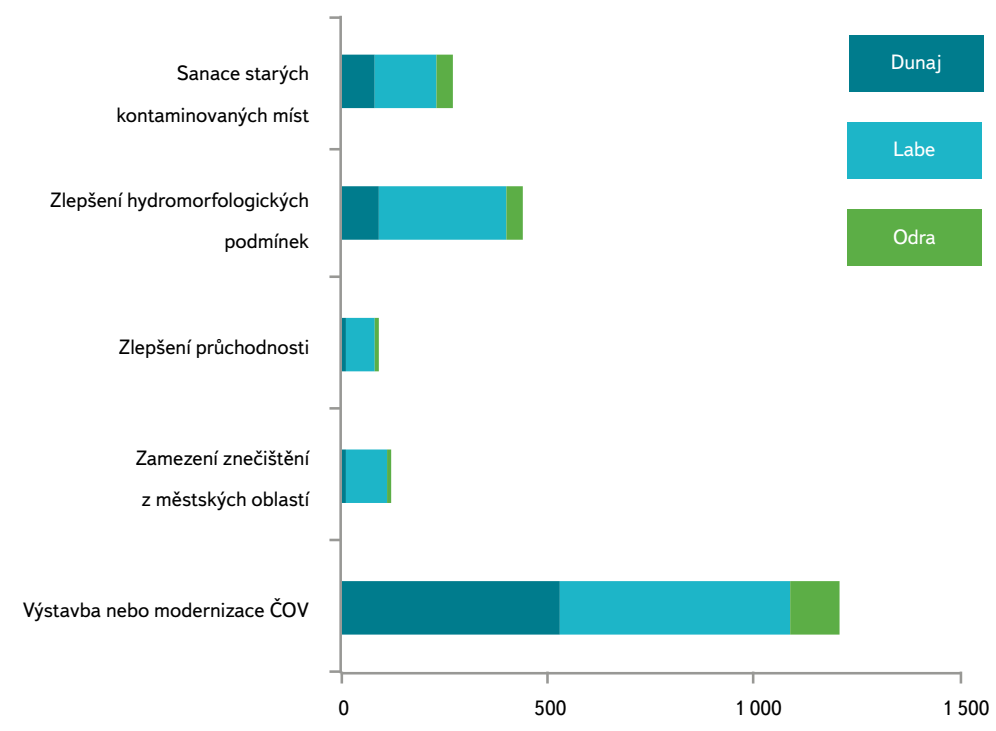

Obr. 25. Nejčastěji navrhovaná opatření - počet (zdroj dat: MZe, VRV a. s.) Fig. 25. Most frequently proposed measures - number (data source: MoA, VRV a. s.)

\section{ZÁVĚR}

V rámci reportingu plánů povodí pro 2. plánovací cyklus podle požadavků Rámcové směrnice o vodách a příslušných pokynů pro reporting byla zpracována poměrně rozsáhlá geodatabáze. Evropská komise využívá reportované informace k posouzení, zda a jak členské státy plní povinnosti vyplývající z Rámcové směrnice ( $v$ souvislosti s 2 . plány zaměřenými zejména na oblast opatření a výjimek z dosažení environmentálních cílů) a rovněž pro analýzy trendů a posouzení účinnosti politik (zejména zlepšení kvality vody v důsledku realizovaných opatření). Na úrovni EU jsou informace poskytovány Evropskému parlamentu, veřejnosti jsou dostupné prostřednictvím systému WISE (Water Information System for Europe) [9].
Současné požadavky na reporting plánů povodí jsou jak po stránce formální, tak po stránce obsahové značně rozsáhlé a komplexní a ze strany členských států je žrejmý tlak na minimalizaci budoucích změn. V oblasti geografických dat bude nicméně v následujícím plánovacím cyklu vyžadováno naplnění požadavků směrnice INSPIRE [10]. Pozornost bude rovněž zaměřena na soulad souvisejících informací reportovaných podle jiných směrnic v oblasti voda.

Na národní úrovni je soubor reportovaných informací a dat včetně jejich statistického vyhodnocení využíván pro prípravu 3. plánovacího cyklu. Analýza údajů umožní zacílení prípravy 3. plánů povodí na dosud problémové oblasti a doplnění príslušných znalostí, potřebných dat a metodických postupů. Jako jedna z klíčových oblastí se napríklad jeví problematika identifikace významných antropogenních vlivů, které brání dosažení environmentálních cílů.

Problematika reportingu byla v roce 2016 řešena spíše v návaznosti na zpracování plánů povodí než jako součást plánování. Obsah plánů povodí se poté ukázal vzhledem k požadavkům na reporting nedostatečný a řada podstatných informací proto musela být pro potřeby reportingu doplňována. Zcela nedostatečná se ukázala př́slušná datová základna vzhledem k požadavkům na kvalitu dat (úplnost, logická konzistence, přesnost a topologická korektnost geografických dat). Požadavky na reporting (co do obsahu i kvality) by proto měly být vzaty v úvahu již při definování obsahu plánů. Zpracování dat a informací pro 3. plánovací cyklus by mělo predcházet vytvoření procesního a datového modelu, který by definoval informační obsah včetně požadavků na kvalitu dat, logické vztahy mezi jednotlivými údaji, datové a informační toky a role v plánování a reportingu zúčastněných institucí. Datový model by měl být doplněn seznamem kontrol kvality prostorových i popisných dat. Zohledněna by měla být i možnost dalšího využití dat pro národní potřeby (vodoprávními úřady, veřejností apod.).

\section{Literatura}

[1] Národní plán povodí Labe [online]. Ministerstvo zemědělství a Ministerstvo životního prostředí, 2015, [cit. 7. února 2017]. Dostupné z: http://eagri.cz/public/web/mze/zivotni-prostredi/ochrana-vody/vodni-ramcova-smernice/planovani-v-oblasti-vod/priprava-planu-povodi-pro-2-obdobi/ narodni-plany-povodi

[2] Národní plán povodí Odry [online]. Ministerstvo zemědělství a Ministerstvo životního prostředí, 2015, [cit. 7. února 2017]. Dostupné z: http://eagri.cz/public/web/mze/zivotni-prostredi/ochrana-vody/vodni-ramcova-smernice/planovani-v-oblasti-vod/priprava-planu-povodi-pro-2-obdobi/ narodni-plany-povodi

[3] Národní plán povodí Dunaje [online]. Ministerstvo zemědělství a Ministerstvo životního prostředí, 2015, [cit. 7. února 2017]. Dostupné z: http://eagri.cz/public/web/mze/zivotni-prostredi/ochrana-vody/vodni-ramcova-smernice/planovani-v-oblasti-vod/priprava-planu-povodi-pro-2-obdobi/ narodni-plany-povodi

[4] Směrnice Evropského parlamentu a Rady 2000/60/ES ze dne 23. řijna 2000 ustavující rámec pro činnost Společenství v oblasti vodní politiky.

[5] WFD Reporting Guidance 2016. Final draft, version 6. 0. 6 [online]. WFD CIS (Water Framework Directive's Common Implementation Strategy), 2016, [cit. 7. února 2017]. Dostupné z: http://cdr.eionet. europa.eu/help/WFD/WFD_521_2016

[6] Guidance on the reporting of spatial data to WISE. Final draft, version 6. 0.6 [online]. WFD CIS (Water Framework Directive's Common Implementation Strategy), 2016, [cit. 7. února 2017]. Dostupné z: http://cdr.eionet.europa.eu/help/WFD/WFD_521_2016

[7] European Environment Information and Observation Network (EIONET), Central Data Repository [online]. [cit. 7. února 2017]. Dostupné z: http://cdr.eionet.europa.eu/

[8] Směrnice Evropského parlamentu a Rady 2013/39/EU ze dne 12. srpna 2013, kterou se mění směrnice 2000/60/ES a 2008/105/ES, pokud jde o prioritní látky v oblasti vodní politiky.

[9] Water Information System for Europe (WISE) [online]. [cit. 7. února 2017]. Dostupné z: http://water. europa.eu

[10] Směrnice Evropského parlamentu a Rady 2007/2/ES ze dne 14. března 2007 o zřízení Infrastruktury pro prostorové informace $v$ Evropském společenství (INSPIRE). 
Autoři

Ing. Petr Vyskoč

凶 petr.vyskoc@vuv.cz

RNDr. Hana Prchalová

凶hana.prchalova@vuv.cz

Mgr. Silvie Semerádová

凶 silvie.semeradova@vuv.cz

Ing. Tomáš Fojtík

网 tomas.fojtik@vuv.cz

Výzkumný ústav vodohospodářský T. G. Masaryka, v. v. i.

Přispěvek prošel lektorským řízením.
REPORTING OF RIVER BASIN MANAGEMENT PLANS UNDER WATER FRAMEWORK DIRECTIVE IN 2016 IN THE CZECH REPUBLIC

VYSKOC, P.; PRCHALOVA, H.; SEMERADOVA, S.; FOJTIK, T.

TGM Water Research Institute, p. r. i.

Keywords: Water Framework Directive - River Basin

Management Plan - water status - water body - programme

of measures - impacts and pressures analysis

In 2015 the River Basin Management Plans (RBMP's) for the $2^{\text {nd }}$ planning cycle under Water Framework Directive were designed and approved. According to the Directive the copies of the RBMP's were sent to the Commission by 22. 3. 2016. In addition the Commission required the results of the RBMP's in the predefined geodatabase structure. A large variety of data was processed to fulfil these requirements. The article has an informative character and is focused on the reporting, not River Basin Management Plans processing. It presents a brief summary of the reporting process and the selected key information on anthropogenic pressures and impacts, water status, exemptions of good status, and programme of measures to meet good status of water bodies.

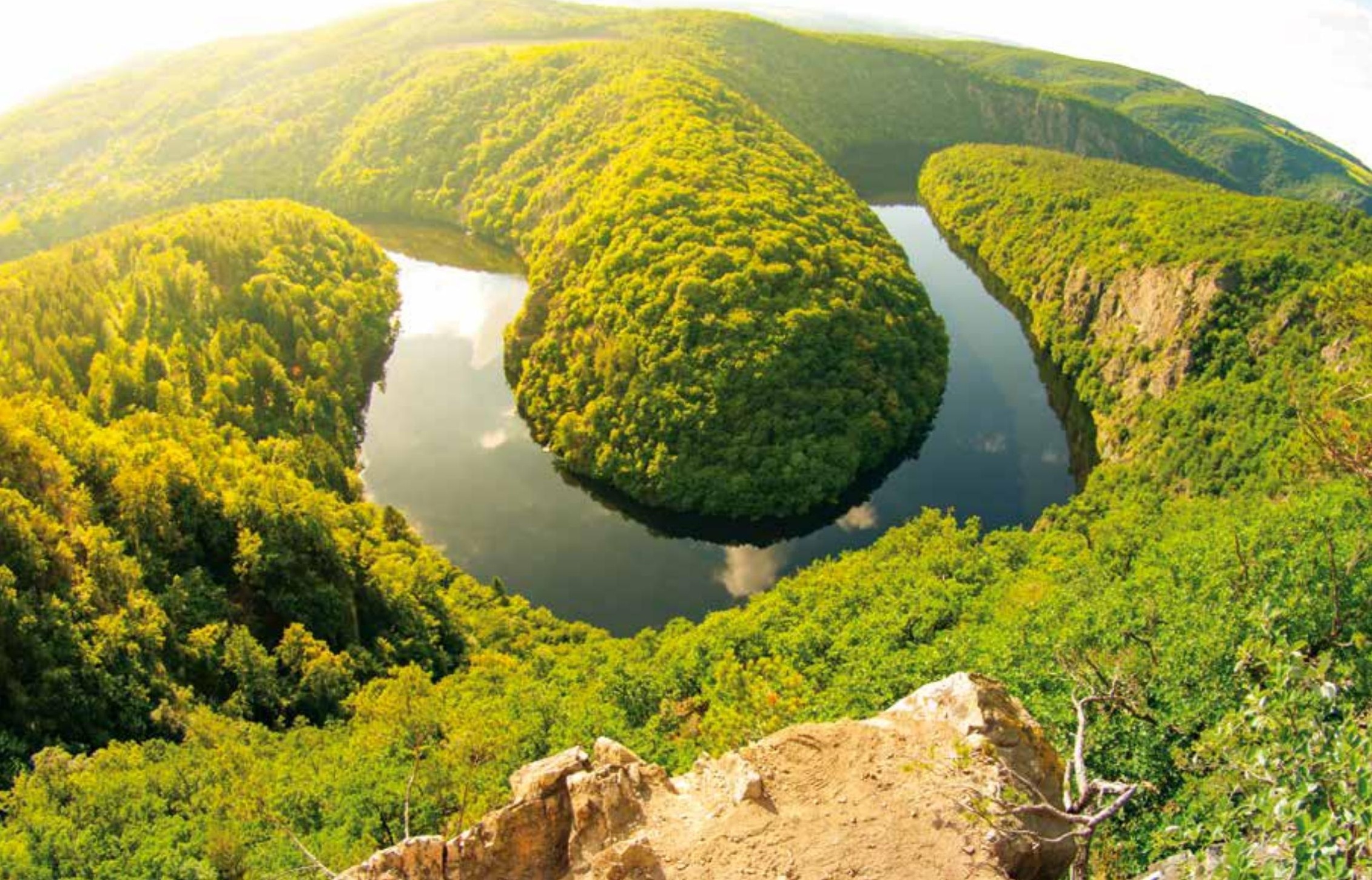

